\title{
Macedonian Cultural Plurality at the Crossroads of the Balkans: Drama, Music and Dance
}

\author{
Sonja Zdravkova Djeparoska \\ Faculty of Music, Ss. Cyril and Methodius University in Skopje, 1000 Skopje, North Macedonia; \\ z.djeparoska@gmail.com
}

Received: 17 May 2020; Accepted: 28 July 2020; Published: 30 July 2020

\begin{abstract}
Defining the Balkans as a geographic, cultural and semantic entity triggers an interpretation of them as some idea, concept, oftentimes even a stereotype. The Balkans are usually interpreted as a singular entity, generalized and set in a single framework. That generalized view is often ambivalent. The Balkans are often interpreted and presented as a 'powder keg', a 'bridge between the East and the West', a part of Europe that is simply different, a place of strong emotions and attractive forms of music and dance, etc. However, the Balkans represent a set of cultural units that are in constant interaction, with each of the cultures of the Balkans being specific and authentic. Macedonia, as one of the pages of the 'Balkan story', will be presented at three levels-regarding its drama, music and dance. The specific characteristics of the music and the dance fields will be presented through their most significant features and examples, and the treatment of the topic of the Balkans in Macedonian drama will be covered as well. The analysis confirms that generalization is impossible even within a single culture, as each artist and medium of performance has its own unique expression. The cultural forms of Macedonian culture are only part of the wider pluralistic representation of the Balkans. It may be offered under the Balkans as the common denominator, but the truth is that this/representation/concept is polyvalent, multicultural, polysemic and extremely rich.
\end{abstract}

Keywords: dance; music; drama; performativity; Macedonia; Balkans

\section{In Search of the Balkans}

In spite of starting to write this text quite enthusiastically and with a sense of familiarity with the general situation and the straightforwardness of things, I was faced with some serious dilemmas at the very beginning of the process. The initial mental structures of the text would have me begin by defining the Balkans, a seemingly clear notion. The Balkan Peninsula-a geographic area considered to be well-defined and definite. However, quite like everything else connected to the Balkans, even the geographic term has achieved a certain quality of mobility/liminality. One can see the extensibility of the term by simply starting with its etymology. Balkan appears to be the name of the mountain (ancient Hemus, in Bulgarian, Stara Planina). The word Balkan comes from Ottoman Turkish balkan 'chain of wooded mountains'. A mountain that metaphorically represents ascent and descent, a certain territory that does not provide visibility like the plain, but instead hides something, limits and divides. The 'mountain' has gradually become a mountain range-a geographic line as well as a border that separates one area (the peninsula) from the rest of Europe. Not only has it become a frontier, but it has also gained the capacity of mobility and shifting, depending on people's needs and desires. "The geographic perception of the area remained unclear for centuries because of the lack of geographic knowledge, but also - and perhaps mainly_-because both the Turks and the Europeans regarded it as a kind of peripheral, as something 'in between' the Western and the Eastern world" (Švob-Đokić 2001, p. 35). The Balkans, along with all the stereotypes surrounding them, are an interesting phenomenon 
that goes beyond the geographic boundaries and creates different interpretive discourses, sometimes even disparate ones.

I continue this seemingly trivial attempt to define the Balkans by typing in the term in several search engines. One of the first results, the one which is used the most, is Wikipedia. While I remain strongly reserved with regard to its unverified and unrefined content, it does clarify some very interesting aspects. This web page ${ }^{1}$ emphasizes the liminality of interpretation and representation of the Balkans, especially since it keeps changing as you select to read the article in a different language (which in turn provides insight into the political positions of the relevant national discourse). One can observe how the Balkans are interpreted through the various articles in each language. The first noticeable difference is in the very title of the articles-the geographic term peninsula (Balkan Peninsula) is part of the title in the articles in Macedonian, ${ }^{2}$ Serbian, Croatian, Bosnian, Albanian and Bulgarian, whereas the English, French and Slovenian articles are titled with the more general term Balkans. The peninsula as a concrete term, denoting one part of the whole, has been replaced by a noun, a name, a designation. The Balkans as a term represent a cultural, political, religious, linguistic and ideological concept. It is a subtle transition from something concrete to something much broader and more general; from geography to representation, image and stereotype. As such, taking into account all its meanings and layered connotations, it cannot be compared to any other peninsula. The Balkans have become a culture, a mentality, an emotion, an energy. Encyclopedia Britannica and Encyclopedia Larousse, ${ }^{3}$ considered as more relevant sources, also use different approach: "There is not universal agreement on the region's components". 4

The peninsula seems to be attaining the figurative meaning of an island. This is a result of both its geostrategic position and the relevant geopolitical interests at any given point in history. This meaning slowly shifted from geography to politics. A lot has been written about the Balkans, its interpretation transitions into myths, stories and symbols. The Balkans as a term-or 'symbolic geography' itself to various, often negative, connotations: “ . . a time-capsule world: a dim stage upon which people raged, spilled blood, experienced visions and ecstasies" (Kaplan 1993, p. 9); “ ... a mystic stronghold of stubborn and belligerent people" (Brown 2015, p. 311); "'primitive', 'backward', 'tribal', 'uncivilized'" (Djurdjević 2008). One of the most widely accepted metaphors for the Balkans is the title of Dejan Dukovski's [Дејан Дукоски] play Powder Keg, as something extremely flammable and highly explosive. This idiom/image of the Balkans relies on historical events (the Balkan Wars as well as the Yugoslav Wars of the 1990s). The general view has been that it should be isolated, detached, preferably kept away from Europe at a safe distance, where it could keep opening and closing the road to the Balkan 'island' should the need arise (regarding accession to the European Union, NATO and other international organizations). One such concept was the political neologism Western Balkans-a solution par excellence for the EU to distance itself from the 'most problematic' part of the Balkans awaiting its chance to join the EU family. "Geographically, the Balkans are a part of Europe, but culturally still

\footnotetext{
https://en.wikipedia.org/wiki/Balkans.

The geographic area of Macedonia as a result of the post-Balkan War Treaty of Bucharest from 1913, was divided into four parts (between Bulgaria, Greece, Serbia and Albania). In this article, I am referring to the part of Vardar Macedonia. This part, after 1913, became a part of Serbia, i.e., Kingdom of Yugoslavia. After World War II and following political changes, (Vardarian part) Macedonia was part of Socialist Federal Republic of Yugoslavia as one of six constitutional republics. The breakup and dissolution of the Yugoslav Republics (1990-1992) initiated secession and then the peaceful declaration of independence of the Republic of Macedonia on 8 September 1991. Because of disagreements over the use of the name Macedonia with Greece and after several decades of negotiation, in 2019 the name was officially changed to Republic of North Macedonia (The Presba Agreement was signed by Greek and Macedonian leaders). The Agreement establishes the use of the name Macedonian for the citizens of North Macedonia, 'Macedonian language' and Macedonian as adjectives. In the article, I am referring to the period after 1991 and in some analyses am going back to the socialist period so would use the terms Macedonian and Macedonia.

3 https://www.larousse.fr/encyclopedie/autre-region/p\%C3\%A9ninsule_des_Balkans/107278.

4 https://www.britannica.com/place/Balkans.

5 The phrase 'symbolic geography' is from the title of Milica Bakić-Hayden's article “Symbolic Geography in Recent Yugoslav Cultural Politics".
} 
do not satisfy the criteria, and are thus defined by a new, political coinage, as the Western Balkans" (Mujagić 2018, p. 8). Milica Bakić-Hayden noted:

Isn't part of the 'battle' of belonging or non-belonging to the Balkans still waged today in some countries of the former Yugoslavia, which 'Europe' in one moment includes and in the other excludes from it, while other countries, for which there is no dilemma of belonging, seem to be 'comforted' by the newly composed syntagm ' the Western Balkans'? Is this the Balkans become part of the 'West' quietly? Or is it a further Balkanization of the Balkans, which the Balkans accept? (Bakić-Hayden 2006, p. 21)

The Balkans is not a very desirable state of affairs, even for the people of the Balkans. The phenomenon of fluctuating boundaries reflects in the position of certain national tendencies to be or to move out of this bounded/limited space. This position is very accurately dealt with in the works "The Spectre of Balkan" of Slovenian philosopher Slavoj Žižek.

"Where does it begin?" For Serbs, it begins down there in Kosovo or Bosnia, and they defend the Christian civilization against this Europe's Other. For Croats, it begins with the Orthodox, despotic, Byzantine Serbia, against which Croatia defends the values of democratic Western civilization. For Slovenes, it begins with Croatia, and we Slovenes are the last outpost of the peaceful Mitteleuropa. For Italians and Austrians, it begins with Slovenia, where the reign of the Slavic hordes starts. For Germans, Austria itself, on account of its historic connections, is already tainted by the Balkanic corruption and inefficiency. For some arrogant Frenchmen, Germany is associated with the Balkanian Eastern savagery. (Žižek 1999)

\section{The Balkans Singular or Plural}

In the languages of the Balkans, the noun Balkans itself is a singular noun, except in Bulgarian where it is plural as well as in English. Although I have no intention of getting into linguistic analysis here, this language fact is certainly thought-provoking. Does the singular form impose an interpretive, conceptual unification of the various elements that the Balkans consist of? Does this incredible treatment of a single territory imply the existence of a generalization process and gradual acceptance of it as a complete, single entity? Finally, is this very common form truly accepted by the peoples of the Balkans? In order to understand the usage of the singular form and to resolve the above-mentioned dilemmas, it is necessary to determine the scope of its use in this homogenized interpretive variant. "Bearing in mind the past and present of cultural pluralism in the Balkans, this geographic region appears as a great metaphor in the social dynamic between globalization and fragmentation" (Djurdjević 2008, p. 165).

Personally witnessing these processes-but also as a resident of the Balkans-it is necessary to emphasize several tendencies visible from the inside. The Balkans singular ('globalization' unification and uniting under the term Balkans) and plural ('fragmentation', conscious separation of units or elements) demonstrate a complex, ambivalent process. As we will see from the analysis below, very often consciously, Balkans as a concept is a matter of acceptance. However, on the other hand, within this concept there is always a need to emphasize and underline specifics (mostly national). The constructed whole for the Balkan population is always visible as a mosaic, collage, patchwork of independent parts that are functioning together.

In this section, certain parallels can be drawn, i.e., a comparison can be made with the Yugoslav cultural model of "unity in diversity" under the common platform-Yugoslav. One may wonder why the concepts of the Balkans and Yugoslavia are joined here when one contains the other. The answer lies within the need to determine the reasons behind pre-established relations. Some of the existing links in culture, festival collaborations, coproductions, are relics of the connections that used to exist among the former Yugoslav republics, which were later expanded with the surrounding countries, i.e., the countries of the Balkans. This transition from Yugoslav to Balkan can be seen in the field of 
culture and it is particularly noticeable after the breakup of Yugoslavia, when the Balkans were seen as a substitute for the Yugoslav cultural concept.

There is an example from the field of folklore, which perfectly illustrates this transition. In order to understand its course, one must first go back to the genesis of this dance formation created during Yugoslavia's socialist times. The Yugoslav concept of "brotherhood and unity" emphasized the value of unity in diversity (today popular under the term multiculturalism); the slogan was meticulously implemented in all segments of life. "It was exactly the celebration of cultural pluralism that enriched natural diversity of Yugoslavia by emphasizing folklore, variety in cuisine, arts, languages, traditions, mass culture, sport, and everyday life in general" (Močnik 2016, p. 225). This is a very transparent way of achieving unity and equality through cultural diversity in the field of folklore. The early years of the federation saw the formation of the national folk dance ensembles Tanec in Macedonia, Kolo in Serbia and Lado in Croatia as the most important articulators of folklore preservation, presentation and production. The repertoire of each of these ensembles included dances from every Yugoslav republic forming the "Yugoslav medley". In this composition, the folk dancers would perform dances from each republic, ending with a dance of their own republic. The performance of the medley in Macedonia would be usually crowned with the Macedonian Kalajdjisko or Crnogorka chain dance. This kind of folk dance compilations continued to live on even after the breakup of Yugoslavia. Adapting to the new political circumstances, these medleys kept the original choreography, but received a new name in accordance with the new political and historical context-the Balkan medley. This trend was quite popular during the 1990s, but its intensity has been decreasing, at least in the Balkans, where monoethnic compositions are much more common. What remains interesting, however, is the tendency for terminological transformations, which take political influences into account and end up substituting Yugoslav with Balkan.

It is paradoxical that Europe, which is based on the idea of multiculturalism, cannot accept the Balkan multiculturalism (Balkan plurality), but treats it as a single entity. "... now Western Balkan countries are again united under the pejorative labeling from European Union representatives (ibid., 236). The interest in the Balkans is undeniable, in spite of all the negative connotations there are; Balkans can be used as an attribute or modifier at different levels.

\section{The Balkans as a Platform for Research, Presentation and Collaboration}

As Djurdjević noted “ ... attributing to the region the status of the unfortunate other of Europe, a collateral damage of modern and civilized Europe" (Djurdjević 2008, p. 158), the Balkans must revise this accepted and stereotypical view. The need to study the Balkans with all their negative and positive implications and to do so within a scientific framework has resulted in the establishment of several Institutes for Balkan Studies ${ }^{6}$ in various countries. They are usually integrated as part of the National Academies of Arts and Sciences (in Serbia, Bulgaria and Bosnia and Herzegovina), which indicates how big of an importance they are given within the national culture. There is also a large number of study programs for Balkan studies at different educational levels (ranging from undergraduate to doctoral studies) not only at universities in the Balkan countries, but also in other parts of Europe and the United States. ${ }^{7}$ The nature of these studies is usually interdisciplinary, so apart from the

6 Institute for Balkan Studies (or "Balkanological Institute"), Serbia (SANU): http://www.balkaninstitut.com/ eng/index.html; Institute of Balkan Studies and Center of Tracology, Bulgaria (BAN): https://balkanstudies.bg/bg/; Balkanology Research Center, Bosnia and Herzegovina (ANUBiH); Institute for Balkan Studies, Greece: http://www.imxa.gr/profile_en.htm.

7 Department of South Slavonic and Balkan Studies, Charles University, Czech Republic: https://www.ff.cuni.cz/home/about/ organization/department-of-south-slavonic-and-balkan-studies/; Balkan studies, Columbia University: https:/harriman. columbia.edu/programs/balkan-studies-program; The Balkan Studies, University of Illinois: http://catalog.illinois.edu/ graduate/graduate-majors/russ-east-euro-studies/balkan-studies-minor/; South Slavonic and Balkan Studies, Masaryk University: https://www.muni.cz/en/bachelors-and-masters-study-fields/24,284-south-slavonic-and-balkan-studies; Balkan studies, University of Copenhagen: https://ccrs.ku.dk/education/balkan_studies/; International Master in Balkan Studies, IBS program, Adam Mickiewicz University, Poznan: https://www.mastersportal.com/studies/228,495/balkan-studies.html. 
linguistic point of view, they also interpret the Balkans from a broader scientific and theoretical level. This approach provides a foundation for the creation of a generalized position, which equates the countries of the peninsula with the general term Balkans.

However, this unification phenomenon is not exclusive to the scientific approach, as it is also present in the field of cultural production. I shall mention several forms of cultural cooperation where the Balkans serve as the common denominator, although clearly underlining that this analysis puts the emphasis on Macedonian culture, dance, music and drama as part of the Balkan cultural collage. I will refer to several cultural manifestations that are in some way related to the Balkans but are initiated in or directly associated with Macedonia. For example, one of the most prestigious international literary awards in Macedonia, apart from the Golden Wreath of the Struga Poetry Evenings, is the Balkanika award. The idea for such an award was promoted at the Racin's Poetry Meetings held in Veles, Macedonia, in 1995. It was accepted by writers and publishers from Greece, Albania, Turkey, Bulgaria and the former Federal Republic of Yugoslavia (today Serbia and Montenegro), while Romania joined the group later. The Balkanika Foundation is based in Sofia. The Foundation presents the award every year and the award-winning writer gets translated and published in the countries of the foundation.

There are examples of networking and cooperation at a Balkan-wide level in the performing arts, too. These collaborations are especially present in the dance field. The Balkan Folklore Festival ${ }^{8}$ was founded in 1962 and is held annually in Ohrid. The festival's initial mission was to present the folklore of the Balkan peoples, but it gradually broadened its scope, became international and started hosting performers from all over the world; nevertheless, the title never lost the Balkan qualifier. As for the field of contemporary dance, Balkan collaborations are particularly intense and have accurately projected dynamics and organization: they are held annually or biennially, at regular periods of the year, the host cities are decided on a rotating basis, organizational structures include representatives of each member states. For example, the Balkan Dance Platform was conceived as a dance fair for contemporary dance artists from all Balkan countries. The festival has been held in Romania, Macedonia, Greece, Serbia. Each platform takes place biennially and includes selected artists from each of the participating countries. Some of its main intentions are including young emerging performers and facilitating networking among the artists for the purpose of planning collaborations and projects. Another form of dance collaboration is Balkan Dance Project. The Macedonian representative (Vol. 1, 2 and 3) was choreographer Igor Kirov. Performer Adrijana Dancheska took part in the Vol. 1 as a dancer. Balkan Dance Project has toured from Slovenia, via Croatia, Bosnia and Herzegovina and Serbia, all the way to Macedonia and Montenegro. This is another example of how cooperation between the former Yugoslav republics is presented as "Balkans". To this series of Balkan collaborative practices, I shall add one more. Even though its title does not have Balkan in it, the essence remains the same. The regional network Nomad Dance Academy was established in 2005 by six Balkan organizations from Serbia (Station), Slovenia (Fičo Balet), Bosnia and Hercegovina (Tanzelarija), Macedonia (Lokomotiva), Bulgaria (Brain Store Project) and Croatia (Tala Dance Center) as a platform for collaboration, creation, promotion and education in the field of contemporary dance. The countries participating in this type of activities usually change. The fact that these joint networks of organizations that manage these projects exist shows that they are active and constitute an important part of the cultural activities, especially in the field of dance. Despite the negative connotation of the Balkans as a term, the Balkan singular functions very well when it comes to its numerous cultural and scientific projects.

8 There is a "Balkan Folklore Festival" also in Varna, Bulgaria and Izmir, Turkey and there are similarly themed (but differently titled) festivals in Serbia and Greece. It is interesting to note that London hosted a "Balkan Music Festival" in 2019 and Emir Kusturica and Goran Bregović performed there with their bands. 


\section{Images from Macedonia-A Cultural Plural. The Macedonian Bal-Kan}

In this section, I will put into play a somewhat controversial and disputed interpretation of the Balkans, that it is of particular importance for this article. It is the combination of two Turkish words: bal 'honey' and kan 'blood'. ${ }^{9}$ I shall therefore, starting from this notion, attempt to interpret the Macedonian creative expression, i.e., their diverse, polyvalent cultural discourses. In one of her op-eds Kica Kolbe (2018) points out that "Balkan person is a cliché; an empty representation which the average Western European uses to name the 'unknown and foreign' person coming from Southeast Europe". In other words, this cliché is made of various contents which are available as the image of the Balkans. The unification of entire production under the umbrella of a single concept may work well beyond these boundaries but is contraindicated in terms of the conditions in this space. As it had already been elaborated, the Balkans are a cultural plurality.

However, at the same time, each of the Balkan national cultures, specifically focusing on the Macedonian, is also a set of characteristics, specifics, nuances. Given the scope of this production, I suggest limitations for each additional criteria in terms of the field, the period and the creative method applied. The interest is set on the performing practices, more specifically stage performances. The selected expressions: drama, music and dance. They demonstrate drastically different content by comparing each other, but also inside each expression separately. Since it is impossible to list and analyze all the stylistic, esthetic, formative properties for each of the selected layers, the focus will be on the most important representatives. The selection of representatives/examples that follow is made according to the criterion of representativeness within the national, Macedonian culture. Each of them carries a recognition marker and has undergone a process of internal and external verification and validation. The 'external' vision of the Balkan cliché in the part of the performance practices is most frequently equated with the folklore. Nevertheless, folklore in particular would not be the focus of this research. As a second constrained parameter is set the author's artistic work. Therefore, in this part, I must emphasize that the images which make up the Macedonian culture are often identified with the individual expressions of the author. For example, when one speaks of the Macedonian film, the first association is Milcho Manchevski's [Милчо Манчевски] opus. In order to be able to follow and affix specific tendencies regarding the created, but also the accepted stereotypes for the Balkans and Macedonia, the research mostly refers to the work after 1991 (the period of Macedonia's independence). The Balkans presence as a topic will be contemplated in the past three decades. In those parts where it is necessary to make a genesis on the existing connections, there would be an opportunity for review also before 1991.

The last criterion in the selection of the materials is the usage of the citation (ready-made matrices), i.e., the process of "recycling", re-actualization in individual art representations (in the field of music due to distinctive popularity, several examples of the popular culture sphere will also be given). The recycling is realized at the level of construction (model) in drama and at the level of form in music and dance. This art formative procedure speaks about the popularity/actuality and even the provocativeness of a certain cultural artefact and the need to actualize it in a new form. The artistic "multiplication" (for example, the writer Stale Popov [СталеПопов] used the song Kalesh Angja as an inspiration for his novel with the same name) makes additional popularization and directs the interest towards separate cultural representatives.

\section{Dramatics of the Macedonian Bal-Kan}

As already was mentioned at the very beginning of the introduction, many countries often try to 'escape' the borders of the Balkans, especially in the political and geostrategic sense. It would be partially possible, at least as a declarative commitment, for countries from the Balkan periphery to

9 Henceforth the term Bal-Kan will be used to denote this particular interpretation of the term Balkan(s). 
declare themselves as belonging to Central Europe ${ }^{10}$ or the Mediterranean. However, this would be impossible to do at the heart of the Balkans. Hence, Macedonia remains 'confined' completely within the Balkan borders. Macedonia has never tried to deny its Balkan provenance, instead making use of it especially in art providing ironic commentary on the stereotypes. The Balkans seem to paint quite an addictive picture, especially for non-Balkan people, as a place of high-frequency oscillation, pronounced dualisms and all-consuming passions. Description of Macedonia as a country full of violence can be found in the of Marija Todorova's book. "The birth of the Macedonian question enhanced the reputation of the peninsula as a turbulent region and of Macedonia as the "land of terror, fire, and sword"' (Todorova 2009, p. 117). This is, namely the picture found in the works of most Macedonian playwrights and film directors who play with the Balkan clichés in a postmodern manner. Macedonian drama and film has embraced the idea of the Bal-Kan with emphasis on the kan. It gets interpreted and artistically recycled in a variety of ways depending on the artistic expression, the artist's approach and individual esthetics. I would start with the folk dramas (bitovi drami) written between the two World Wars. Studying their topic, Jelena Lužina (1985) points out one very interesting peculiarity: "If they want to be 'fashionable', they will write everyday folk life stage plays with singing and shooting, and not folk dramas or tragedies portrayed as 'exclusively Macedonian'". Those "shooting and singing" plays are the equivalent of the Bal-Kan interpretation. Many Macedonian authors have used this constructed image; the images of blood, victims, death and violence is ever present in Macedonian literature. The writer Slavko Janevski [Славко Јаневски] was one of the first who attempted to poetically present these images in his poem Zagatlivi balkanski prašalnici [Perplexing Balkan Conundrums]:

By wounds and decay the day's rendered grey.

In a jackal's mind, does a corpse mean breath?

Severed heads, blood pooling neath, giving way.

In an eagle's beak, what's the smell of death? (Janevski 1966, p. 30) $)^{11}$

Macedonian playwright Dejan Dukovski is said to be "one of the most successful export products" (Lužina 2012, p. 9). His latest printed collection of plays sees three plays out of fifteen containing Balkan in the title (Balkan's Not Dead, The Last Balkan Vampire and Balkan St. 3a/II). Many of the other plays relate to the image of the 'Macedonian Balkans' as a European Pandora's box of sorts, but they are not directly named after it (Powder Keg, Who the Fuck Started All This Mess). The picture of an uncivilized, fierce, high-tension space leads to paroxysm. "Perhaps the author's starting idea is that all meaningful strong emotions have now become irrelevant and completely profane, so the new European drama that follows, having Dukovski himself as the initiator of this trend, shall operate on the following keywords: blood, sperm, sweat" (Stojanoska 2018, p. 115). Dukovski embraces and expands the construct predominantly developed by the 'Western' perception of the Balkans, adding a strong dose of irony and sarcasm to his idiosyncratic postmodern writing style. For Dukovski this space is sealed in the genetic code of each of his characters. A code that sculpts the absurdity of living which always ends in death, nevertheless a rather violent death, an act of revenge, affect, impatience. Writing about the new generation of post-Yugoslav playwrights, which includes Dejan Dukovski, the author Naum Panovski notes: "This young generation is close to its contaminated ground and in their works there is less optimism, fewer utopian images and more postmodern nihilism and cynicism" (Panovski 2006, p. 68). In several of his plays, the author refers to the existing historical and artistic matrices, whereas the most dominant one is done in The Balkans are not dead, where he

10 This classification notably became relevant after the fall of the Iron Curtain and the European integration of the Eastern Bloc countries. The question of the borders of Central Europe in relation to the Balkans is a point which is especially relevant in the cases of Slovenia and Croatia, seen as some kind of border zone. More on this topic in "Between Classification and Politics the Balkans and the Myth of Central Europe" by Todorova (2009, pp. 140-60).

11 Translated for the purpose of this article by Nina Tunteva. 
makes a re/de/construction of the cult folk drama by Vojdan Chernodrinski [Војдан Чернодрински] The Macedonian Bloody Wedding. There, Dukovski completely recreates the relationship between the characters and the dramatic situations. In his peculiar style, the well-known ending of Chernodrinski's original piece, is replaced with the unexpected twist that leads to "the completion of the action with a pathetic-parody comment" (Petkovska 2008, p. 176). The introduction of the Balkan's Not Dead sets the action in 1905, but the description also applies to events that take place a century later. In the play's introduction Dejan Dukovski writes:

Europe at the beginning of the century ... enthusiasm for unification The Balkans at the beginning of the century ... knee-deep in blood. (Dukovski 2012, p. 343)

His plays are filled with passion, hatred and blood. His original sensibility makes him particularly interesting, contemporary and provocative. With his authentic, unique and artfully expressed discourse, Dukovski has created works that are performed not only in the Balkans, but also on stages around the world. The play Powder Keg has been translated into 18 languages and performed on 35 stages from Germany to Russia, through France, Austria and Denmark, to Sweden, Japan and beyond. This speaks of the relevance of the image depicted in the play, the image of a world that is fierce, brutal and violent. "Balkan trend of voluntary self-exoticism" (Brown 2015, p. 311) is one of characteristics of Dukovski's dramaturgy. An image of Macedonia as part of the Balkans which those who are not from the area create and wish to see.

\section{Sounds of the Macedonian Bal-Kan}

The next stop is musical layer. The representation of a space in this case the national is also related to its sound characterization. The first association (of course there are exceptions) for the sound/music which determines this space is mostly associated with folklore. That is interpreted through the importance of the tradition for each of the Balkan peoples, but also in the political and cultural processes. Can the Macedonian traditional music be generally defined? The answer is negative because it owns many regional, local and genre features. This analysis will not deal with interpretation of the original traditional music examples (as stated before) but will follow the process of their 'recycling' in the works of the Macedonian composers of popular and classical music.

In spite of the fact that there is a trend, in the context of the Balkan unit to promote and present "Balkan Music" which is a kind of a hybrid, yet this unification has been associated merely with musical trends in recent times. As the most important representative of this wave, we single out Goran Bregović and his Orchestra for Weddings and Funerals. Unlike the presence of motifs and allusions on the subject of the Balkans in Macedonian drama, Macedonian music rarely (almost never) accepted the label "Balkan Music" (Wilson 2020), nor has created hybrid genres that will flirt with the vision of the Balkans in the eyes of the 'other'. The interest about tradition, the presence of different re-creating models are connected with music heritage and it is strongly emphasized in Macedonia past decades. There are more reasons, from which I would single out the place of this cultural layer in the process of national establishment and promotion. On the official website of Tanec, ${ }^{12}$ a proverb current in the times of Yugoslavia was written:

There is one saying among the inhabitants of former Yugoslavia that goes: 'Don't sing when you're passing through Bosnia and Herzegovina, don't dance when you are passing through Serbia, but don't you dare to dance and sing when you're passing through Macedonia because you will be over-sang and over-danced'.

Even though the country in which this proverb was used, does not exist for three decades, the attractiveness of its content, which glorifies Macedonian culture, still makes it even more popular. A similar view is shared by Velika Stojkova Serafimovska and Dave Wilson:

12 http://www.tanec.com.mk/. 
While some music scenes have developed since Macedonia's independence from Yugoslavia in 1991, many of them have roots in the Yugoslav era, when Macedonia was stereotyped as the constituent republic with the best musicians, dancers, and traditional songs, a stereotype that continues to some extent today across genre boundaries. (Stojkova Serafimovska and Wilson 2019)

The connection with the cultural scene of Yugoslavia is not something unexpected. As already noted, there are trends that place these existing relationships and ties on a new footing, offering them as Balkan (co) productions. ${ }^{13}$ French philosopher Henri-Louis Bergson argues that the past is preserved in the present through a process of actualization "the present contains nothing more than the past, and what is found in the effect was already in the cause" (Bergson 2002, p. 178). He dwells on processes that act towards the relation perception, memory and category time (past-present). Reactivation/reactualization/representation, i.e., the revival of the past, i.e., of certain fixed structures are strongly present in Macedonia. The idea of a republic where "they sing and dance the best" creates an excellent basis for continuing this memory, not only in terms of preserving traditions (in the way of interpretation, freezing or petrification of the music or the dance content, etc.), but also through forms that quote, model and reshape.

When contemporary authors turn to the tradition, they take on the most significant features that make this region recognizable. They predominantly use three specific features: rhythm, vocal melodies and folk instruments. Kiril Djaikovski [Кирил Џајковски], whose fame reaches beyond the borders of the Balkans, confirms in one of his interviews his use of these three levels when composing (even though this particular case refers to his film music, his approach is identical when working in other genres too). "It (the music-author's note) always adapts to the film narrative in question and merges orchestrally arranged themes with various modern aspects, enriched by strong percussions as well as ethno influences and the use of traditional instruments" (Trajkovski 2018, p. 190).

The contemporary composers often 'borrow' the melody from the folk songs and dances. Macedonian songs as Zajdi, More Sokol Pie, Tvoite Ochi Leno Mori, Kalesh Angja, Makedonsko Devojche, Biljana Platno Beleshe and many more are often used. If we take as example the song Kalesh Angja, it is used as the base melody in several works of contemporary and popular music. Kalesh Angja is part of the thematic material of the ballet Tashula the Ohrid Slave (2004) by Stojan Stojkov [СтојанСтојков]. The composer links it to the main character Tashula, so it acts as a leitmotif guiding her through the whole composition. Aleksandar Trajkovski emphasizes the place of the sound of tradition in film music: "Most films have the sonic color of musical folklore, whether it is directly referenced or taken as the basis of original themes" (Trajkovski 2018, p. 200). He identifies the Kalesh Angja theme in two films, Shadows (directed by Milcho Manchevski, cover by Duke Bojadjiev [Дуке Бојаџиев]) and Balkan's Not Dead (directed by Aleksandar Popovski, music by Kiril Djaikovski). Celebrating the occasion of the twentieth anniversary of independent Macedonia, the multimedia project Makedonium by Marjan Nechak [Марјан Нечак] was performed. The composition uses melodic material from several folk songs, including Kalesh Angja. Dave Wilson equates the act of using the song in this performance context with the effect of constructing parallels with the historical past. "Though no text was used in the performance, many Macedonians would recognize the song and its subtle assertion of Macedonian identity against its principal historic foreign oppressor, consistent with anti-colonial nationalist tropes." (Wilson 2019, p. 22) The Macedonian jazz scene has also used traditional songs. As an example we have selected Ilija Pejovski [Илија Пејовски] compositions. He made jazz arrangements of Ne si go prodavaj Koljo chiflikot and Serbez Donka songs (Novakovska 2001, 2012).

13 The Balkans as a cooperation platform is particularily used in projects in the field of the contemporary (music) art. They are often funded by the European funds and programs. I will refer Ergon Ensemble's Balkan Project (2016) with the participation of women composers. Macedonia was represented by Darija Andovska [Дарија Андовска]. As well the Balkan session on Music Harvest (Musikhost) where was performed contemporary music of Macedonian composers Goce Kolarovski [Гoце Коларовски], Jana Andreevska [Јана Андреевска], Soni Petrovski [СониПетровски] and Darija Andovska. 
The second level, i.e., the second characteristic besides the reference of the melodies, is the use of uneven/additive rhythms. I would like to refer to Pajdushko oro (Paidushko chain dance). As a sound material it is embedded in two compositions of the Macedonian contemporary composers, both of which are written in 5/8 m. Prelude Paidushka for piano is composed by Zhivoin Glishich [ЖивоинГлишиќ]. This piece of artwork is often present in the program of the Macedonian pianist Simon Trpceski [Симон Трпчески] and is very popular (often performed as a final part at the request of the audience, as an encore). The young pianist and composer Dino Imeri [Дино Имери] uses the same rhythmic pattern in his Allusion Tempo di Pajdushko.

Folk instruments are often used to create a contemporary sound image of Macedonia. One of the first to use this creative principle was Gligor Smokvarski [ГлигорСмокварски] in the ballet Macedonian Story (1953). In the part of the ballet named after the Teshkoto chain dance (oro), he introduced a tapan (large drum) and combined it with the sound of the orchestra. Dragan Dautovski [Драган Даутовски] uses only traditional instruments in his concerts but integrates them by having a contemporary approach to the performance. Folk instruments are used in popular music as well. The so-called "ethno bands" (Anastasia, Ljubojna, Monistra) create the sound diversity by using instruments such as kaval (end-blown flute), tapan, zurla (zurna, wind instrument), etc. or instruments that are part of the Chalgia tradition kanoon, tambourine (dajre) and oud (The Chalgia Sound System). Moreover, the groups that are part of the Macedonian rock scene Mizar and Kismet in some of their performances include kaval, tapan and gajda (bagpipe), which is not specific to this style of music (Žabeva-Papazova 2008; Jabeva Papazova 2009).

By actualizing the sound that the most often characterizes Macedonia (based on tradition/folklore, the sound of different regions and different genres, examples that have risen above the others in terms of their recognizability) it was represented in a new musical form articulated through the terms of the present.

\section{Dances of the Macedonian Bal-Kan}

Each of the performance spheres (drama, music) ending with dance, treated the term Balkans with a different interest. From conscious manipulation and intensification of stereotypes with the Bal-Kans template, to engaging and actualizing one's own specifics which are primarily related to folklore, i.e., its most dominant features. The dance establishes a two-way relationship with the term Balkans. Macedonian dances were part of a project called 'Yugoslav Folklore'. Not only did the "Yugoslav medley" (already mentioned) and dances from Yugoslav republics spread in professional ensembles, but also on an amateur level and in that way disseminated. ${ }^{14}$ Overcoming the Yugoslav federation, we noticed interest in the Balkan dances (interpreted as a complex, including music as well) since the mid-twentieth century, but in a much broader context. The fascination with Balkan dances (not in the form mentioned above but expanded to also include all other Balkan countries) is evident not only in the countries of Europe, but perhaps even more intensely so in the United States (Laušević 2007; Ivanova-Nyberg 2011). Exploring the phenomenon of the Balkan dances' extreme popularity, ethnochoreologist Daniela Ivanova-Nyberg wrote the following:

The popularity of line dances, as it was mentioned to me, stems not only from the fascination of Balkan music, but also because dancing in a line and holding hands appears to be deeply reflective of the spirit of the time. Dancers discovered in Balkan music and dance something they subconsciously yearned for and could not find in their increasing industrialized society.

14 Another form through which various folk dances from Yugoslavia were studied and disseminated was the Ljetna Škola Folklora (Summer Folk Dance School), founded by Croatian ethnochoreologist Ivan Ivančan. Dances representing The Vardar dance zone (Macedonian dances) were taught by prominent Tanec dancers Stanimir and Rada Vishinski [Станимир и Рада Вишински]. 
For many of them learning the first steps of kolos began a long journey in exploring the cultures of the Balkans. (Ivanova-Nyberg 2011, p. 6)

The middle of the 20th century saw a particularly rapid establishment of clubs, camps and courses of Balkan dance and music. This kind of dance evenings that combine different dances from Macedonia, Serbia, Bulgaria, Greece highlight the unit known as Balkan dances and music. Anatol Joukowsky, a Russian emigrant who spent part of his life in the Kingdom of Yugoslavia and then moved to the United States after the war, writes about this trend. Joukowsky was one of the organizers of those 1950s and 1960s courses and workshops where Balkan dances were studied, danced and passed on. In one of his essays he notes, "People have always shown great interest in my subject Dances of the Balkan peoples, in which Macedonia plays a significant part" (Joukowsky 1986, p. 860). This tendency persisted into the beginning of the 21 st century. "The very repertoire the Balkanites are drawn to fosters group experience and social enjoyment of music and dance in the ways many other musical styles do not" (Laušević 2007, p. 55). The Balkans, in the form of music and dance, have become fascinating, alluring, bewitching.

A reflection on the unification idea (the Balkan plural) in the part of the author's artistic segment is found in the first Yugoslav national ballets. As an example, we take the ballet Ohrid Legend by Stevan Hristić. Hristić supplemented and expanded the first version of one act (1933) into four acts (1947). The so-called character suite (a form that we follow in the ballets of Tchaikovsky and Glazunov) is included in the 3rd act with dances of the Balkan peoples (Romania, Bulgaria, Greece, where through the main character Biljana, Macedonia/Yugoslavia is represented). Although it is a highly stylized national dances actualizes the trend of creating a collage segment with national attribution.

"Traditional dance cultures still challenge conventional means of storing of the past" (Hardt 2011, p. 32) The folklore in each of the Balkan peoples was and is still treated as an identification marker. It is interesting that the most dominant traditional chain dance Teshkoto ${ }^{15}$ which identifies the Macedonians has never been a part of the "Yugoslav medley" and almost never have been part of schools and courses for the Balkan dances. The first leader of the ensemble Tanec Emanuel Chuchkov [Емануел Чучков] in the text "Ideological Content and Rhythmic Processes in Macedonian Folk Dance" wrote "Teshkoto is a prototype of the Macedonian dance style" (Chuchkov 1951, p. 65). The question of favoring a particular dance as a prototype can be problematic, especially in relation to the repeatedly mentioned fragmentation of culture, including the dance. However, the interest that follows, namely this dance, starting from the 30s of the 20th century in the time of the Kingdom of Yugoslavia, the socialist Macedonia and the independent Republic of Macedonia is evident. This is confirmed by the huge number of papers written on this topic by domestic and foreign authors (Ivančić-Dunin and Višinski 1995; Mironska Hristovska 2002; Zdravkova Djeparoska and Opetcheska Tatarchevska 2012; Wilson 2014; Silverman 2015; Stojkova Serafimovska et al. 2016; Zdravkova Djeparoska 2019). One of the most versatile and dedicated researchers of Macedonian dance, Ivančić-Dunin, notes "'Macedonian dance' is often synonymous with an image of Teškoto-a line of pill-box-capped men holding hands, the support leg is flexed while the other leg is lifted forward, the lead dancer is perched on one leg on top of a drum" (Ivančić-Dunin and Višinski 1995, p. 263). The dance has become a myth in the Macedonian cultural context and beyond. Teshkoto translates to 'the hard one' and it refers to the manner of performance-it is hard, calm, restrained. The dance was first described by the Janković sisters, Serbian ethnochoreologists who traveled around the territory of the Kingdom of Yugoslavia and made notes of different dances, described the sociocultural contexts and transcribed the choreographies in their books. They noted the following on the Teshkoto from Lazaropole: "Every movement is psychologically justified and deeply experienced" (Janković 1948, p. 22). This performance-related feature will serve as a ground for replenishment with new meanings. The process of gaining a concrete content is mostly

15 Teshkoto is male dance originating from north-west part of Macedonia, belonging to the ethnographic conglomeration of Reka (River). 
related to the poem of the same name by the Macedonian writer Blazhe Koneski [Блаже Конески]. In it, he poetically describes the folk dance and unifies it with centuries of slavery, conquer and struggle for freedom. Teshkoto through this performance has been imposed literally as a symbol of the past.

This traditional folk dance creates an incredible reflection in the author's work. Teshkoto as a motif has been exploited in many works of fine art, music and dance art. Macedonian composer Vlastimir Nikolovski [Властимир Николовски] quite often addressed this issue in his pieces of work, writing seven different compositions on Teshkoto. Nevertheless, we single out the first Macedonian national ballet Macedonian Story by Gligor Smokvarski. The composer places the culmination in the part called Teshkoto. The ballet was staged twice in 1953 and 1993 on the stage of the Macedonian National Theater in Skopje. The actualization of the work, eight years after Yugoslavia was established, i.e., only four years after the creation of the first ballet ensemble in Macedonia, speaks of the need to emphasize national cultural features. The cyclical actualization of the ballet only two years after the proclamation of Macedonia's independence confirms the same tendency, in the course of which it is intensified through the libretto. Unlike the original libretto, on Anton Panov [АнтонПанов] play The Migrants, the director Ljubisa Georgievski [љубиша Георгиевски] wrote a new one for the version in 1993. The libretto symbolically tried to present the "tragic fate" and the history of the Macedonian people. The work soon after the premiere (due to a copyright dispute) was removed from the repertoire, but they still remains an intense impact on the Macedonian culture. In the first version from 1953 (choreographied by Dimitrije Parlić), one can notice the need for and attempt of maximum approximation to the term Macedonian folklore in the part of costume design (almost authentic costumes, the dancers danced in opinci-peasant footwear), but also in the part of the choreography. The choreographer Olga Milosavleva [Олга Милосавлева] introduced a change in Teshkoto (1993). This new presentation of Teshkoto on a ballet stage created an art product which was accepted as a projection of the original performance. The ballet part Teshkoto became one of the central performances at tours in Macedonia, but also abroad.

Teshkoto is one of the most important representative performances of the Macedonian culture, its "recycling" in several artistic forms speaks of the need to actualize this moving image of Macedonia.

\section{Conclusions}

The Balkans should not be mythologized, imagined, glorified or degraded. This attitude is, namely crucial for the interpretation of this space, as it is part of a larger entity that has its own specifics, but not as drastic as they are defined from the outside. It would be completely wrong to represent everything by a single color, sound or movement, when it is in fact a kaleidoscope of cultural units which compose the image of the Balkans as a part of Europe.

When I attempted to summarize the views on the Balkans by addressing the difference between cultural singularity and plurality, I emphasized the Macedonian cultural context. Following the Macedonian author's work in the part of the performance expression, it can be concluded that the Balkans theme gets a various resonance in each of the interpreted examples. The intensified dramatic treatment has actualized a certain image about it. In contrast, music and dance did not contemplate directly with the Balkans but were and are part of community-based projects. Projects in which they operate at a multicultural projections level (separate part of the whole, visible and nationally determined). At least in terms of the Macedonian presence, we follow this kind under the umbrella of the Yugoslav idea, ${ }^{16}$ which would later be transformed and offered as a Balkan production. Nonetheless, never in an intercultural presentation (as the only hybrid form of Balkan music or dance). Regardless

16 The Yugoslav attribution in the period of independence is most extremely pronounced through the choice of the name of the state-Former Yugoslav Republic Of Macedonia (FYROM) in the most important international organizations UN, EU, NATO. 
these processes, Macedonian culture has promoted its own representatives who receive their reflection 'recycling/in the works of art.

Macedonian culture, which is part of the Balkan landscape, proves the thesis of the plurality and cultural diversity that is difficult to reduce to a common factor in terms of style, model, performance and esthetics, but at the same time serves as an element of the complex matter of the Balkans-pulsating in its own rhythm, but still part of the organism of a larger entity.

Funding: This research received no external funding.

Conflicts of Interest: The authors declare no conflict of interest.

\section{References}

Bakić-Hayden, Milica. 2006. Varijacije na temu 'Balkan' [Variations on Balkans Theme]. Belgrade: Institut za filozofiju i društvenu teoriju: "Filip Višnjić".

Bergson, Henri. 2002. Key Writings. Edited by Keith Ansell Pearson and John Mullarkey. New York and London: Continuum.

Brown, Keith. 2015. Independence: Art E Activism/A Conversation with Milcho Manchevski. Edited by Marina Kostova. MANCHEVSKI Monograph. Skopje: Ars Lamina-Publikacii, pp. 311-13.

Chuchkov, Manoil (Чучков, Маноил). 1951. Идејната содржина и ритмичките процеси во македонската народна игра [Ideological Content and Rhythmic Processes in Macedonian Folk Dance]. Sovremenotst I: 60-68.

Djurdjević, Maria. 2008. The Balkans: Past and Present of Cultural Pluralism. IEMed. Available online: https://www.iemed.org/publicacions/quaderns/12/The_Balkans_Past_and_Present_of_Cultural_ Pluralism_Maria_Djurdjevic.pdf (accessed on 23 June 2019).

Dukovski, Dejan (Дуковски, Дејан). 2012. Драми [Plays]. Skopje: Kultura.

Hardt, Yvonne. 2011. Staging the Ethnographic of Dance History: Contemporary Dance and Its Play with Tradition. Dance Research Journal 43: 27-42. Available online: www.jstor.org/stable/23266824 (accessed on 14 June 2020). [CrossRef]

Ivančić-Dunin, Elsie, and Stanimir Višinski. 1995. Dances in Macedonia: Performance Genre, Tanec. Skopje: Tanec Ensemble.

Ivanova-Nyberg, Daniela. 2011. A ‘Balkan Folk Dance' Phenomenon in the United States: A Few Analytical Observations. Porte Akademik Journal of Music and Dance Research 2011: 38-45.

Janevski, Slavko (Јаневски, Славко). 1966. Евангелие по ИтарПејо [Gospel of Itar Peio]. Skopje: Kocho Racin. Janković, Ljubica, and Danica (Јанковић, Љубица и Даница). 1948. Народне игреIV [Folk Dances IV]. Belgrade: Prosveta.

Joukowsky, Anatol (Жуковски, Анатолиј). 1986. Македонската народна игра на балетската сцена меѓу двете светски војни [Macedonian Folklore in National Ballet Scene between Two World Wars]. In Македонскиот фолклор во музикото и драмското творештво до1945 [Macedonian Folklore in Music and Dramatic Creation up to 1945]. Skopje: Macedonian Academy of Sciences and Arts (MANU), pp. 82-87.

Jabeva Papazova, Julijana (Жабева-Папазова Юулияна). 2009. Новият сингл на Мизар`Бяло море’ в контекста на политическата и културно-естетическа сцена в Македония [The New Single of Mizar- Byalo More (Aegean Sea) in the Context of Political and Cultural-Aestetic Scene in Macedonia]. In Изкуство и контекст [Art and Context]. Haskovo: BAN, pp. 161-73.

Kaplan, Robert D. 1993. Balkan Ghosts. A Journey Through History. New York: St. Martin's Press.

Kolbe, Kica. 2018. Балканскиот менталитет [The Balkan Mentality]. DW.COM. Available online: https://www.dw.com/mk/балканскиотменталитет/a-48526464 (accessed on 30 October 2019).

Laušević, Mirjana. 2007. Balkan Fascination: Creating an Alternative Music Culture in America. Oxford: Oxford University Press.

Lužina, Jelena (Лужина, Јелена). 1985. Историја на македонската драма: македонска битов $a$ драм $a$ [Нistory of Macedonian Drama: Macedonian Folk Drama]. Skopje: Kultura, Available online: http://makedonija.rastko. net/cms/files/books/4c29480693299 (accessed on 28 January 2017). 
Lužina, Jelena (Лужина, Јелена). 2012. Preface. In Plays [Драми]. Skopje: Kultura.

Mironska Hristovska, Valentina (Миронска-Христовска, Валентина). 2002. Тешкото-Релација меѓу поезијата и народната игра [Teshkoto-The Relation Between Poetry and Folk Dance]. In Literary Context. Skopje: Institute of Macedonian Literature, pp. 141-46.

Močnik, Nena. 2016. Brotherhood and Unity Goes Multiculturalism: Legacy as a Leading Path toward Implementations of New European Multiculturalism. In Titoism, Self-Determination, Nationalism, Cultural Memory. Edited by Gorana Ognjenović and Jasna Jozelić. London: The Palgrave Macmillan, pp. 215-53.

Mujagić, Nermina. 2018. Understanding 'Strategic Narratives' on the Balkans and its Borders. In Perspectives, Political Analyses and Commentary. Edited by Srđan Dvornik. Sarajevo: Heinrich-Böll-Stiftung, pp. 7-12.

Novakovska, Eleni [Новаковска, Елени]. 2001. фолклорот и џезот: Темата Не си го продавај Кољо чифликот преки композиторскиот ракурс на Илија Пејовски [Folklore and Jazz: Theme Ne si go prodavaj Koljo chiflikot in Ilija Pejovski Composition]. In Music. Skopje: Sokom, pp. 69-76.

Novakovska, Eleni [Новаковска, Елени]. 2012. Илија Пејовски Бас [Ilija Pejovski Bas]. In Struga Music Autumn Collection. Skopje: Sokom.

Panovski, Naum. 2006. New Old Times in the Balkans. The Search for a Cultural Identity. Paj-a Journal of Performance and Art 28: 61-74. [CrossRef]

Petkovska, Nada [Петковска, Нада]. 2008. Македонската современо драмско творештво и идентитетот [Macedonian Contemporary Drama and Identity]. In Lectures at the XVth International Seminar on Macedonian Language, Literature and Culture. Skopje: University Ss. Cyril and Methodius University, pp. 169-83.

Stojanoska, Ana (Стојаноска, Ана). 2018. Театар: предизвик. Студии и есеи [Theater: A Challenge. Studies and Essays]. Skopje: Ss. Cyril and Methodius University.

Stojkova Serafimovska, Velika, Dave Wilson, and Ivona Opetčeska Tatarčevska. 2016. Safeguarding Intangible Cultural Heritage in the Republic of Macedonia. Yearbook for Traditional Music 48: 1-24. [CrossRef]

Stojkova Serafimovska, Velika, and Dave Wilson. 2019. Macedonia: Modern and Contemporary Performance Practice. In The SAGE International Encyclopedia of Music and Culture. Edited by Janet Sturman. Thousand Oaks: SAGE Publications, Available online: http://sk.sagepub.com/reference/the-sage-international-encyclopediaof-music-and-culture/i13383.xm (accessed on 15 June 2020).

Silverman, Carol. 2015. Macedonia, UNESCO, and Intangible Cultural Heritage: The Challenging Fate of Teškoto. Journal of Folklore Research 52: 233-51. [CrossRef]

Švob-Đokić, Nada, ed. 2001. Balkans Versus Southeastern Europe. In Redefining Cultural Identities: Southeastern Europe. Zagreb: Institute for International Relations, pp. 35-45.

Todorova, Maria. 2009. Imagining the Balkans. Oxford: Oxford University Press.

Trajkovski, Aleksandar (Трајковски, Александар). 2018. Музиката во македонскиот игран филм [The Music in the Macedonian Film]. Skopje: Kinoteka na Makedonia.

Wilson, Dave. 2014. Teškoto and National Sentiment in Macedonia: Ascribing Meaning, Experiencing Tradition. In Terminology and Theoretical Approaches and Crossing Boundaries/Intercultural Communication Proceedings of the Third Symposium of the ICTM Study Group For Music And Dance in Southeastern Europe. Edited by Elsie Ivancich Dunin, Liz Mellish and Ivona Opetcheska-Tatarchevska. Skopje: ICTM Study Group on Music and Dance in Southern East Europe, National Committee ICTM Macedonia, pp. 242-49.

Wilson, Dave. 2020. Not Dierent Enough: Avoiding Representation as 'Balkan' and the Constrained Appeal of Macedonian Ethno Music. Arts 9: 45. [CrossRef]

Wilson, Dave. 2019. Shaping the Past and Creating the Future: Music, Nationalism, and the Negotiation of Cultural Memory at Macedonia's Celebration of Twenty Years of Independence. Music $\mathcal{E}$ Politics 13. Available online: https:/quod.lib.umich.edu/m/mp/9460447.0013.202?view=text;rgn=main (accessed on 3 June 2020).

Žabeva-Papazova, Julijana. 2008. The Influence of Macedonian Folk Music on the Development of Macedonian Alternative Music post 1991. In Musical Folklore as a Vehicle? Belgrade: SMS, IMS, and FM, pp. 99-106.

Zdravkova Djeparoska, Sonja, and Ivona Opetcheska Tatarchevska [Здравкова-Џепароска, Соња, ОпетческаТатарчевска, Ивона]. 2012. ‘Тешкото' помеѓу поетското и танцовото ['Teshkoto' Between Poetry and Dance]. Spektar 30: 98-108. 
Zdravkova Djeparoska, Sonja [Здравкова-Џепароска, Соња]. 2019. From Teshkoto to Macedonian Postmodern Dance. Skopje: SZD.

Žižek, Slavoj. 1999. The Spectre of Balkan. Journal of the International Institute 6. Available online: https://quod.lib. umich.edu/j/jii/4750978.0006.202/-spectre-of-balkan?rgn=main;view=fulltext (accessed on 30 September 2019). 